\title{
The Market Orientation of Local Governments as a Function of Entrepreneurship: a Theoretical Approach
}

\begin{abstract}
Nowadays, in conditions of globalisation, and simultaneously with tendencies to decentralise management at the level of states and regions, individual territorial units (cities, municipalities, regions) are forced to adopt a more proactive, market-oriented approach to development. This process requires constant analysis of the environment and response to emerging changes; consideration of the offers of the competition and customer's expectations. The purpose of this article is to show a market approach to managing the development of territorial units as a function of entrepreneurship. In particular, to show the relationship between the market orientation of local governments and entrepreneurship. This is understood, on the one hand, as a process of identifying and using opportunities and on the other, as a process of creating new enterprises, where special attention is paid to the emerging idea of territorial units as entrepreneurs. The latter concept appears increasingly frequently in the literature and colloquial language. Market orientation is an expression of the entrepreneurship of local government. Its impact on entrepreneurship on a given territorial unit is a new and important research area that requires exploration. The paper is based on the theoretical discussion using selected literature on the subject.
\end{abstract}

Keywords: entrepreneurship of the city; entrepreneurship of the region; gmina entrepreneurship; market orientation of local governments; public management

Recieved: 24 October 2019

Accepted: 15 April 2020

\section{Suggested citation:}

Zdon-Korzeniowska, M. (2020). The Market Orientation of Local Governments as a Function of Entrepreneurship: a Theoretical Approach. Przedsiębiorczość - Edukacja [Entrepreneurship Education], 16(1), 237-246. doi: 10.24917/20833296.161.19

\section{Introduction}

Contemporary socio-economic changes are incredibly dynamic while their scope, course and structure are also impressive. All this significantly transforms the operating conditions not only of individuals and business entities but also of entire societies and national economies. 
The tendency to increase the freedom and speed of the flow of capital and people as well as goods and services opens up special opportunities for businesses and citizens. These possibilities are related to the freedom to choose the place of business, residence, work and leisure. These create special prospects, but also serious challenges for places of investment, enterprises and people, and thus for territorial units. Today, individual places compete for development factors not only locally but also internationally (Pilewicz, 2013: 1). To meet the requirements of the global market, they must demonstrate flexibility, innovation and a market approach, adapting to the needs of interested groups: entrepreneurs, tourists, residents, investors (Zdon-Korzeniowska, 2011: 188).

The adoption of a market approach by local governments seems to be an imperative today. In the literature on the subject, there is the term "market orientation" (MO), which is used interchangeably with the term "marketing orientation" and "customer orientation" (Kowalik, 2010: 45). Despite the often alternative uses of these terms, a common part, which undoubtedly draws attention to the addressees of the offer, satisfies needs and communication; it is reasonable however to indicate a certain difference by a hierarchy of these three concepts. The term "market orientation" is the widest because, by its very name, it describes a focus on the "market", i.e. customers, competitors, suppliers and other market entities. "Marketing orientation" seems to be slightly narrower paying attention to marketing activities undertaken in relation to the identified groups of recipients. The narrowest is "customer orientation", which means striving to meet the needs of customers. Nevertheless, the effectiveness of both "marketing orientation" and "customer orientation" requires taking into account the activities of other market players, such as competitors. Hence it seems reasonable, despite the differences (including those in the methods of examining these phenomena) to specify the following concepts: "market orientation", "marketing orientation" and "customer orientation". This is also often the case in the literature on the subject.

According to Kuźniar (2013: 9), the success of a territorial unit is largely determined by the adoption and implementation of a marketing orientation aimed at satisfying current and future recipients of the territorial offer. It is understood as a set of utilities offered in the given area to interested groups - residents, tourists, investors, etc., coordinated and animated by the authorities of a given territorial unit ${ }^{1}$.

The purpose of this article is to show a market approach to managing the development of territorial units as a function of entrepreneurship. The discussion leads towards finding a logical connection between the concepts and phenomena appearing in the literature describing the activities of territorial units which are aimed at increasing their competitiveness and functioning in the conditions of the market and, more broadly, the global economy. In particular, it aims at showing the relationship between the market orientation of local governments and entrepreneurship. From the perspective of management science, the latter is understood as, on the one hand, a process of identifying and using opportunities, while on the other, as a process of creating new ventures (Landström, 2010). Special attention is paid to the concept of entrepreneurship of territorial units (regions, cities, municipalities, etc.) emerging in the literature and everyday language. The study is a theoretical discussion using selected literature on the subject.

${ }^{1}$ Territorial marketing uses the term "territorial mega product", which consists of so-called 'territorial sub-products', e.g. tourist, investment, cultural and educational, recreational and sports, etc. 
Public sector reform trends as the basis for forming a market approach

in managing the development of territorial units

The market approach to the management of local government units is the aftermath of contemporary reform trends of the public sector. Its beginnings should be seen in the concept of so-called New Public Management (NPM) (Walker et all, 2011: 707), which appeared as a response to the demand for public administration reforms at the turn of the 1980s. NPM is an approach derived conceptually from theories in economics (including the theory of public choice and the theory of transaction costs), consisting in introducing reforms based on the experience of management in the private sector (Rudolf, 2010: 76). The reforms proposed under NPM focused mainly on activities related to increasing the efficiency of public organisations, customer orientation, promoting competition between service providers and adopting elements of strategic management. The basis of many principles of this trend is marketing elements such as focusing on customer needs and a quick response to changes in the environment (Kowalik, 2010).

NPM was met with a wave of criticism which undermined the legitimacy of using economic criteria in the public sector. Direct response to this criticism was the concept of so-called 'public governance' 2 which is a broader approach, to a large extent taking into account the socio-political and economic environments, the complexity of relations (Szumowski, 2014: 93-94) and the related need to manage the network. The reference point in this concept is civil society (Izdebski, 2007: 7). And while in NPM the reference point is citizens as consumers, in public governance activity focuses on citizens as stakeholders (Izdebski, 2007: 16). Therefore, we can speak of public governance as complex management of relationships involving many stakeholders (public and private partners, citizens, entrepreneurs, etc.) (Szumowski, 2014: 94).

One of the latest approaches to the functioning of public sector administration is the concept of the Neo-Weberian State proposed by Pollitt and Bouckaert (2011). It is a kind of collage of positive elements of the earlier ideas (i.e., a model based on Weber's classic bureaucracy, NPM, and co-governance) (Oramus, 2016: 51). However, it is above all a direct response to contemporary global threats, including the economic crisis of the early 21 st century. This concept assumes, in particular, increasing the supervisory and regulatory role of the state. It is also an attempt to modernise traditional bureaucracy towards making it more professional, efficient, and citizen-friendly (Pollitt, Bouckaert, 2011: 19).

As mentioned above, the beginnings of market orientation, also referred to as customer orientation, should be seen primarily in NPM. Nevertheless, the contemporary reform trends of the public sector that follow it seem to support the necessity and importance of referring their activities to the needs and expectations of recipients/clients (as in NPM), whether understood as stakeholders (in the case of joint management) or only as citizens (in the concept of the neo-Weberian state).

${ }^{2}$ The term New Public Governance (NPG) also functions in the literature on the subject (cf. Osborne, 2006, 2010). 
Market orientation: essence and definitions

Generally speaking, market orientation means adopting a proactive, customer-oriented approach which considers external environmental conditions (Walker et all, 2011: 708). According to the definition of Jaworski and Kohli (1993, quoted after Kowalik, 2010: 45) "market orientation consists in the whole organisation collecting market information, in particular regarding current and future needs of customers, passing this information to all cells of the organisation, and then reacting to this information". As emphasised by Kowalik (2010: 45), market orientation understood in this way means that all organisational units and not just the marketing department should demonstrate a market-oriented approach. Szromnik (2008: 60) also indicates this aspect as an important element of marketing orientation, noting that "the dominant element of this concept is the adoption by the employees the philosophy of customer service".

Another approach to market orientation, leading to similar observations, was proposed by Narver and Slater (1990). When defining market orientation, the authors point to three of its behavioural components, i.e. customer orientation, competitor orientation and inter-functional coordination. They also mentioned two additional decision criteria, i.e. profitability and long-term focus (Narver, Slater, 1990: 21-22). Customer orientation means a proper understanding of the recipients (target market), who they are and what they want, to be able to provide them with the highest value in the form of a properly prepared product. The authors point out (after Levitt 1980) the need for continuous improvement activities in the so-called 'extended product', which is after all the main area of competition in terms of a product. In addition, the authors point to the need to understand the entire value chain for the buyer. The second component, i.e. orientation to competition, requires knowledge of strengths and weaknesses, and the long-term opportunities and strategies of key competitors, both current and potential. The third behavioural component, i.e. cross-functional coordination, means the coordinated use of company resources (both human and financial) in order to create better quality for target customers. It is about involving the entire organisation, not just one department, using the effects of synergy. The taxonomy of the approaches defining the concept of market orientation is presented in Table 1.

Table 1. Categories of approaches to defining the market orientation

\begin{tabular}{|l|l|l|}
\hline \multicolumn{2}{|c|}{ Market orientation } \\
\hline Definition & $\begin{array}{l}\text { adopting a proactive, customer-oriented approach, taking into account } \\
\text { the conditions of the external environment } \\
\text { (Walker et all, 2011: 708) }\end{array}$ \\
\hline B.J. Jaworski, A.K. Kohli (1990, 1993) & J.C. Narver, S.F. Slater (1990) \\
\hline Definition & $\begin{array}{l}\text { consists of collecting information } \\
\text { about the market by the entire } \\
\text { organisation, in particular } \\
\text { regarding current and future } \\
\text { needs of customers, passing this } \\
\text { information to all cells of the } \\
\text { organisation, and then reacting to } \\
\text { this information }\end{array}$ & $\begin{array}{l}\text { includes three behavioural } \\
\text { components: } \\
\text { customer orientation, competition } \\
\text { orientation and cross-functional } \\
\text { coordination } \\
\text { and two decision criteria: } \\
\text { profitability and the long term }\end{array}$ \\
\hline
\end{tabular}

Source: author based on Narver, Slater (1990), Jaworski, Kohli (1993), Walker et all (2011) 
Of the theoretical approaches to marketing orientation mentioned above, the approach of Jaworski and Kohli deserves special attention. It is widely cited in the literature and used in numerous academic studies because of the practical scale for measuring market orientation, the so-called MARKOR (Kowalik, 2010: 51). This method was first adopted and used to measure market orientation in the public sector in Spain (Carver, Molla, Sanchez, 2001) and in Australia (Caruana, Ramaseshan, Ewing, 1998). An interesting approach to measuring market orientation in public sector organisations, also based on the approach of Jaworski and Kohli, was used by the Portuguese researchers Rodrigues and Pinho (2011). The authors assessed the market orientation of public organisations in two dimensions: external and internal. An external dimension is a traditional approach to marketing activities oriented towards clients and markets. The internal dimension, however, refers to the concept of internal marketing, which in the literature on service marketing is considered one of the key factors in improving the quality of services and a kind of a tool to motivate employees.

In Poland, research on the market orientation of local governments was carried out by Kowalik $(2010,2011)$. As the results of the author's work have shown, in most Polish local governments, it is medium; only slightly more than one-fifth have adopted a high degree of market orientation (Kowalik, 2010: 131). Market/marketing orientation research in Poland has also been carried out by Szromnik (2008) on the marketing orientation of cities, by Borodako (2006) on the promotional and informational activity of powiats, and Kuźniar (2013) on the marketing activity of gminas (cf. Table 2).

Table 2. Market orientation research in the public sector - authors and research areas

\begin{tabular}{|l|l|l|}
\hline \multicolumn{1}{|c|}{ Author } & \multicolumn{1}{c|}{ Year, country } & \multicolumn{1}{c|}{ Research areas } \\
\hline $\begin{array}{l}\text { A. Caruana, B. Ramaseshan, } \\
\text { M.T. Ewing }\end{array}$ & 1998, Australia & $\begin{array}{l}\text { universities and public sector } \\
\text { organisations }\end{array}$ \\
\hline A. Carver, A. Molla, M. Sanchez & 2001, Spain & public organisations \\
\hline A.P. Rodrigues, J.C. Pinho & 2011, Portugal & $\begin{array}{l}\text { public organisations (external } \\
\text { and internal) }\end{array}$ \\
\hline I. Kowalik & 2010, 2011, Poland & local governments \\
\hline A. Szromnik & 2008, Poland & Cities \\
\hline K. Borodako & 2006, Poland & Powiats \\
\hline W. Kuźniar & 2013, Poland & Gminas \\
\hline J. Anders-Morawska, W. Rudolf & 2015, Poland & Cities \\
\hline $\begin{array}{l}\text { N. Derlukiewicz, A. Mempel-Śnieżyk, } \\
\text { T. Pilewicz, M. Zdon-Korzeniowska }\end{array}$ & 2017, Poland & Gminas \\
\hline
\end{tabular}

Source: author based on Caruana, Ramaseshan, Ewing (1998), Carver, Molla, Sanchez (2001), Rodrigues, Phino (2011), Kowalik (2010, 2011), Borodako (2006), Szromnik (2008), Kuźniar (2013), Pilewicz et all (2018)

According to Szromnik, "the marketing orientation of a settlement unit is a set of its structural and functional features, along with a system of accepted and respected values and views, expressing the priority treatment of customers in all fulfilled tasks for the benefit of the local community" (Szromnik, 2006: 76). The orientation of a gmina, powiat or province understood in this way assumes (Szromnik, 2006: 76):

- specific thinking of authorities and employees,

- a specific internal organisation of local government institutions, 
- proper terms and procedures for customer service,

- adequate criteria for employee assessment and motivation,

- appropriate ways of setting and achieving the objectives and the tasks arising from them.

Summing up, we can say that the market orientation of local governments consists in their adopting a proactive approach which is oriented to the needs of customers such as residents - current and potential, entrepreneurs, investors, tourists and others. It needs to take into account the conditions of the external environment, including the behaviour of competitive units.

\section{The market orientation of local government and entrepreneurship}

In the literature on the subject above, we find the view that market orientation contributes to increasing the performance of an organisation. This is also confirmed by research conducted in public sector organisations in Poland and elsewhere in the world (Kowalik, 2011) which shows that market orientation helps to reduce the cost of services provided by local governments. Moreover, adopting a market orientation by local government administration increases the participation of citizens in management (citizen participation), results in a better adaptation of services to their needs and better citizen-government communication (Kowalik 2010: 52-53, 59-60). It also affects the efficiency and market behaviour of local enterprises by limiting transaction costs (Pilewicz, 2016). Adoption of market orientation by a local government positively affects the improvement of the entrepreneurial climate in a given territorial unit by identifying the needs of investors and entrepreneurs while creating an investment offer of a given area in terms of these needs.

Trying to indicate the relationship between the market orientation of local government and entrepreneurship, it is also necessary to define the concept of entrepreneurship itself. Entrepreneurship is an ambiguous concept, and as a research area is characterised by multidisciplinarity and interdisciplinarity (Wach, 2015). Most often, these issues are raised in the field of economic and management sciences; more and more often it is an issue addressed in socio-economic geography and spatial management. Makieła indicates that entrepreneurship combined with its inherent feature of innovation "are perceived as elements of the management and marketing process that allow identifying, forecasting, stimulating and satisfying the needs of clients, partners and distancing competitors" (Makieła, 2013: 19). In this context, the author distinguishes regional entrepreneurship by describing it as part of the management process of a specific territorial unit (region, powiat or gmina), "whose purpose is to obtain benefits resulting from the implementation of spatial order and aim to meet the needs of residents" (Makieła, 2013: 20).

Changes in the functioning of local governments and their environment mean that there is a demand for entrepreneurial local government management (Kożuch, B., Kożuch, A., 2013). As indicated by M. Bednarczyk (2001: 136), today public organisations are forced to "operate according to market rules similar to the behaviour of enterprises". Kowalik (2010: 58) emphasises that many factors influence the level of market orientation. They include the size of the organisation, features of senior management, dynamics of the environment and, what is worth paying special attention to in the context of this study, entrepreneurship understood as a feature of local government organisation. We can, therefore, say that the adoption of market orientation by a given territorial unit 
is an expression of its entrepreneurial behaviour. The market approach to managing a territorial unit means, among others, the need to analyse the environment in terms of identifying emerging opportunities and then using them to stimulate development.

Entrepreneurship understood as a trait of an organisation (in some simplifications local government units are often treated as such) is often referred to as so-called intrapreneurship' (Bednarczyk, 2001), i.e. internal entrepreneurship. It is defined by Bednarczyk (2001: 135) as a feature of individuals or organisations characterised by sensitivity to change, innovativeness (i.e. seeking and introducing innovations) and willingness to take risks. The adoption of a market approach by territorial units, which, among others, shows openness to changes occurring in the environment (including changes in the needs and preferences of recipients), active search for opportunities, using them for development and identifying competitors, can undoubtedly be recognised as entrepreneurial behaviour.

To sum up, we can say that on the one hand entrepreneurship understood as a feature of local government is one of the factors affecting the level of market orientation of a territorial unit. On the other hand, market orientation is a characteristic feature of an entrepreneurial unit. For several decades, we have been talking about the concept of place entrepreneurship appearing in the literature (e.g. Hall, Hubbard, 1996; Jessop, 1997, 1998, 2003; Klasik, 2005; Kożuch, B., Kożuch, A., 2013; Pilewicz, 2012, 2013, 2016; Płaziak, Rachwał, 2015; Szromnik, 2012; Zdon-Korzeniowska, 2011; Zheng, 2011).

Enterprising local governments recognise the need to compete for capital, investments, residents, tourists and investors. Creating favourable conditions for investment contributes to reducing transaction costs for enterprises (Pilewicz, 2016; Pilewicz et all, 2018). These include creating the right infrastructure, providing information on the local labour market, designating investment locations, improving investor services, offering tax breaks and support in setting up an enterprise. As a result, a territorial unit, which is an inherent feature of an entrepreneurial territorial unit, contributes to supporting the development of entrepreneurship in its area (see Figure 1).

Finally, it should be noted that the concept of entrepreneurship of a territorial unit is not fully defined. It is a relatively new term, often used intuitively, and the definition examples found in the literature cover selected aspects relating to specific types of territorial unit. Identification of the entrepreneurial features of a gmina, city or region is often done by analogy with the entrepreneurial features of an organisation (cf. Bednarczyk, 2001; Pilewicz, 2012). This seems to be a good direction, ordering the issues discussed by referring to knowledge already established in the functioning of enterprises or organisations.

Figure 1. Entrepreneurship and market orientation in a local government unit

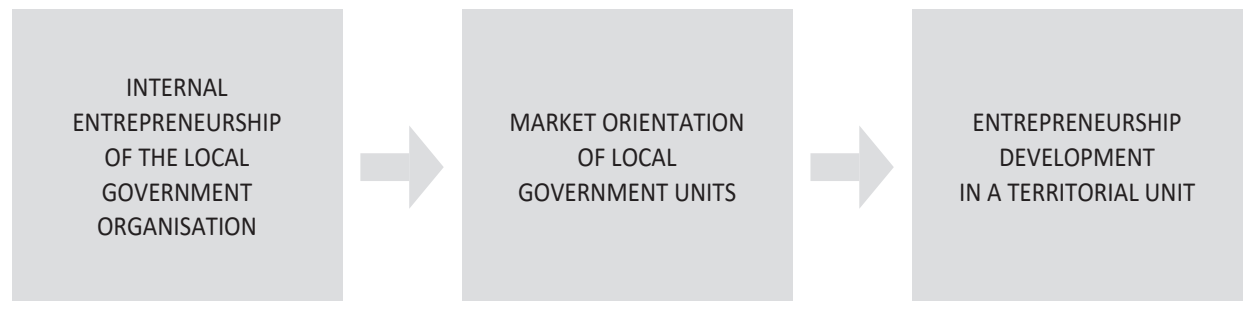

Source: author 
Summary

Market orientation as an expression of the entrepreneurship of local governments, and its impact on entrepreneurship in a given territorial unit, is an essential research area that requires exploration. The discussion in this study aimed at showing market orientation as the basis for the development of entrepreneurship of a territorial unit understood, on the one hand, as the ability of a given local government to engage in marketing behaviour, by identifying clients and competitors, perceiving opportunities and using them for development, and on the other as the functioning and development of enterprises within a given unit. The starting point is the assumption that the market approach (market orientation) is a feature of the entrepreneurial approach in managing the development of a given territory (i.e. the entrepreneurial territorial unit). In addition, it was also intended to demonstrate that market orientation contributes to the development of entrepreneurship in the sense of the creation and development of enterprises in a given area.

The discussion here was conducted mainly from the perspective of management sciences, mainly due to market orientation issues. Nevertheless, taking into account the second aspect i.e. the concept of entrepreneurship, including territorial entrepreneurship, and its interdisciplinary character as emphasised in the literature, it should be noted that the perspective adopted here is only one of many possible. The analysis deliberately omits concepts on regional development and territorial local government that go far beyond the accepted view. However, they would undoubtedly enrich it and constitute an interesting research area.

The market orientation of local government means that a given territorial unit in managing its development operates according to market principles as a quasi-enterprise. By managing the resources at its disposal (human, material, financial and information), it identifies and satisfies the needs of its clients (residents - current and potential, tourists, investors and other financial market entities, and cultural, social, political organisations, etc.). It also takes into account the offer and activities of its competitors (i.e. other territorial units with a similar type of offer). What is an entrepreneurial region, municipality or city? What features does an entrepreneurial local government unit have? To what extent can we talk about entrepreneurial local government or an entrepreneurial territorial unit? Undoubtedly, these questions pose a challenge and the answers require further academic exploration.

\section{References}

Andres-Morawska, J., Rudolf, W. (2015). Orientacja rynkowa we wspótrządzeniu miastem. Łódź: Wydawnictwo Uniwersytetu Łódzkiego.

Bednarczyk, M. (2001). Organizacje publiczne. Zarządzanie konkurencyjnością. Warszawa-Kraków: PWN.

Borodako, K. 2006. Działalność promocyjno-informacyjna polskich powiatów w kontekście wspierania przedsiębiorczości na podstawie badań bezpośrednich. Samorzą Terytorialny, 4, 28-40.

Caruana, A., Ramaseshan, B., Ewing, M.T. (1997). Market orientation and organizational commitment in the Australian public sector. International Journal of Public Sector Management, 10(4), 294-303.

Carver, A., Molla, A., Sanchez, M. (2001). Antecedents and consequences of market orientation in public organizations. European Journal of Marketing, 35, 11-12. 
Derlukiewicz, N., Mempel-Śnieżyk, A., Pilewicz, T., Zdon-Korzeniowska, M. (2018). Investment Offer as an Expression of Marketing Orientation of Polish Local Governments in the Context of their Investment Attractiveness. Prace Komisji Geografii Przemysłu Polskiego Towarzystwa Geograficznego, 32(3), 98-115.

Hall, T., Hubbard, P. (1996). The Entrepreneurial City: New Urban Politics, New Urban Geographies? Progress in Human Geography, 20(2), 153-174.

Izdebski, H. (2007). Od administracji publicznej do public governance. Zarzadzanie Publiczne, 1, 7-20.

Jaworski, B.J., Kohli, A.K. (1993). Market orientation: Antecedents and Consequences. Journal of Marketing, 57, 53-70.

Jessop, B. (2003). Governance and meta-governance. On reflexivity, requisite variety, and requisite irony. In: H.P. Bang (ed.), Governance as Social and Political Communication. Manchester: Manchester University Press, 101-116.

Jessop, B. (1998). The rise of governance and the risks of failure: the case of economic development. International Social Science Journal, 155, 29-46.

Jessop, B. (1997). The governance of complexity and the complexity of governance. In: A. Amin, J. Hausner (ed.), Beyond Markets and Hierarchy: Interactive Governance and Social Complexity. Chelmsford: Edward Elgar, 111-147.

Klasik, A. (2005). Przedsiębiorczość i konkurencyjność a rozwój regionalny. Kluczowe pojęcia i metodologia. Biuletyn Komitetu Przestrzennego Zagospodarowania PAN, 218, 7-22.

Kohli, A.K., Jaworski, B.J. (1990). Market Orientation: The Construct, Research Propositions, and Managerial Implications. Journal of Marketing, 54(2), 1-18.

Kowalik, I. (2010). Orientacja rynkowa w polskim samorzadzie terytorialnym. Warszawa: Oficyna Wydawnicza Szkoła Główna Handlowa.

Kowalik, I. (2011). Market orientation and its antecedents in the Polish local governments. International Journal of Public Sector Management, 24(1), 57-79.

Kożuch, B., Kożuch, A. (2013). Przedsiębiorczość w zarządzaniu samorządowym. Zarzadzanie Publiczne, 2(22), 137-147.

Kuźniar, W. (2013). Aktywność marketingowa gmin i jej oddziaływanie na rozwój turystyki wiejskiej. Rzeszów: Wydawnictwo Uniwersytetu Rzeszowskiego.

Landström, H. (2010). Pioneers in Entrepreneurship and Small Business Research. Heidelberg: Springer.

Levitt, T. (1980). Marketing Success Through Differentiation—of Anything. Business Harvard Review, January Issue.

Makieła, Z. (2013). Przedsiębiorczość i innowacyjność terytorialna. Region w warunkach konkurencji, Warszawa: Wydawnictwo C.H. Beck.

Never, J.C., Slater, S.F. (1990). The Effect of a Market Orientation on Business Profitability. Journal of Marketing, 54(4), 20-35.

Oramus, M. (2016). Neoweberowskie państwo w kontekście globalnego kryzysu ekonomicznego. Myśl Ekonomiczna i Polityczna, 1(52), 37-55.

Osborne, S.P. (2006). New Public Governance. Public Management Review, 8(3), 377-387.

Osborne, S.P., (red.) (2010). New Public Governance? Emerging Perspectives on the Theory and Practice of Public Governance. London: Routledge.

Pilewicz, T., Derlukiewicz, N., Mampel-Śniezyk, A., Zdon-Korzeniowska, M. (2018). Entrepreneurial Activity, Market Orientation, Investment Attractiveness and Transaction Costs for Enterprises in Local Development Context. Barometr Regionalny, 16(3), 109-119.

Pilewicz, T. (2012). Region jako organizacja przedsiębiorcza w zarządzaniu strategicznym. Kwartalnik Nauk o Przedsiębiorstwie, 3, 27-35.

Pilewicz, T. (2013). Marketing terytorialny jako rynkowa koncepcja pozyskiwania czynników rozwojowych regionów. Monografie i Opracowania. Szkoła Główna Handlowa, 594, 33-50. 
Pilewicz, T. (2016). Entrepreneurial activities of gminas in creation of competitive advantages at regional investment markets: Entrepreneurial organization model. Entrepreneurship: Antecedents and Effects. Przedsiębiorczość Międzynarodowa, 2(2), 129-146.

Płaziak, M., Rachwał, T. (2015). „Przedsiębiorczy region” - zarys koncepcji w świetle analizy roli przedsiębiorczości w krajowej strategii rozwoju regionalnego. Przedsiębiorczość - Edukacja [Entrepreneurship - Education], 11, 37-49.

Pollitt, Ch., Bouckaert, G. (2011). Public Management Reform. A Comparative Analysis - New Public Management, Governance, and the Neo-Weberian State, 3 ed. Oxford: Oxford University Press.

Rodriguez, A.P., Pinho, J.C. (2011). The impact of internal and external market orientation on performance in local public organisations. Marketing Intelligence \& Planning, 30(3), 284-306.

Rudolf, W. (2010). Koncepcja governance i jej zastosowanie - od instytucji międzynarodowych do niższych szczebli władzy. Acta Universitatis Lodziensis. Folia Oeconomica, 245, 73-82.

Szromnik, A. (2006). Marketing terytorialny - koncepcja ogólna i doświadczenia praktyczne. W: Marketing terytorialny. T. Markowski (red.), TOM CXVI, Warszawa: PAN KPZK.

Szromnik, A. (2008). Marketing terytorialny. Miasto i region na rynku. Wyd. II. Kraków: Wolters Kluwer.

Szromnik, A. (2012). Miasto przedsiębiorcze i innowacyjne w regionie. Zeszyty Naukowe Uniwersytetu Szczecińskiego. Ekonomiczne Problemy Usług, 98, 323-346.

Szumowski, W. (2014). Zarządzanie publiczne - próba systematyzacji koncepcji. Nauki o Zarządzaniu, $4(21), 86-98$.

Wach, K. (2015). Przedsiębiorczość jako czynnik rozwoju społeczno-gospodarczego: przegląd literatury. Przedsiębiorczość - Edukacja [Entrepreneurship - Education], 11, 24-36.

Walker, R.M., Brewer, G.A., Boyne, G.A., Avellaneda, C.N. (2011). Market Orientation and Public Sector Performance: New Public Management Gone Mad? Public Administration Review, 71(5), 707-717.

Zdon-Korzeniowska, M. (2011). Przedsiębiorczość samorządów terytorialnych w warunkach globalizacji. Przedsiębiorczość - Edukacja [Entrepreneurship - Education], 7, 188-196.

Zheng, J. (2011). 'Creative Industry Clusters' and the 'Entrepreneurial City' of Shanghai. Urban Studies, 48(16), 3561-3582.

Małgorzata Zdon-Korzeniowska, PhD, assistant professor at the Department of Entrepreneurship and Spatial Management in the Institute of Geography of the Pedagogical University of Krakow. Her research interests include market orientation of local government, territorial marketing, management of tourism at a local and regional level, regional tourism products.

\section{Adres/Address:}

Uniwersytet Pedagogiczny im. Komisji Edukacji Narodowej w Krakowie

Instytut Geografii

Zakład Przedsiębiorczości i Gospodarki Przestrzennej

ul. Podchorążych 2

30-084 Kraków, Poland

e-mail: malgorzata.zdon-korzeniowska@up.krakow.pl 